\title{
Bridging the Gap between Individual and Corporate Responsible Behaviour: Toward a Performative Concept of Corporate Codes
}

\author{
Vincent Blok ${ }^{1}$
}

Published online: 22 November 2016

C) The Author(s) 2016. This article is published with open access at Springerlink.com

\begin{abstract}
We reflect on the nature of corporate codes of conduct is this article. Based on John Austin's speech act theory, four characteristics of a performative concept of corporate codes will be introduced: 1) the existential self-performative of the firm identity, 2) which is demanded by and responsive to their stakeholders; 3) Because corporate codes are structurally threatened by the possibility of failure, 4) embracing the code not only consists in actual corporate responsible behaviour in light of the code, but in the incessant recapturing of the code in the struggle of firms against the possible incongruence between their ethical principles and their actual responsible behaviour. A performative concept of corporate codes helps to bridge classical dichotomies like individualist versus collectivist approaches of moral agency and restrictive versus empowering ethics, and opens a new perspective on the interaction between individual ethical behaviour and the corporate institutionalisation of codes.
\end{abstract}

Keywords Corporate code $\cdot$ Code of conduct $\cdot$ Corporate responsibility Performativity $\cdot$ Austin

\section{Introduction}

Companies increasingly attempt to respond to the expectations of their stakeholders (customers, governmental organisations, special interest groups) in order to enhance and secure their license to operate. Profitability is no longer the only driver for these companies, but also the acceptance by the stakeholders affected by their business operations: "The social license is based not on legal requirements but, rather, on the degree to which a corporation and its activities meet the expectations of local communities, the wider society, and various constituent groups" (Gunningham et al. 2004: 313). Over the years, an increasing amount of

Vincent Blok

vincent.blok@wur.nl

1 Management Studies Group and Philosophy Group, School of Social Sciences, Wageningen

University, Hollandseweg 1, 6707 KN Wageningen, The Netherlands 
companies started to participate in roundtables, Multi-Stakeholder Alliances (MSAs) and Cross-Sector Partnerships (CSPs) in order to interact with and learn from stakeholders, negotiate norms and standards, and integrate these norms in the business operations (cf. Dentoni et al. 2012).

Codes of conduct or codes of ethics can be seen as the way these norms and standards are operationalized within firms. A code of conduct is a set of principles and rules providing a formal framework of responsibilities and proper actions for an individual or a firm. They prescribe or proscribe employee or professional behaviour. Codes of ethics prescribe and proscribe professional behaviour too, although in a different way. They do not concern specific instructions or rules concerning employee or professional behaviour, but encourage them to perform ethical characteristics like loyalty, honesty and integrity. Although there are many differences between codes of conduct and codes of ethics, they can be seen as the terms and conditions of the license to operate of firms: "By adopting its own code, a company can clarify for all parties, internal and external, the standards that govern its conduct and can thereby convey its commitment to responsible practice wherever it operates" (Paine et al. 2005). Nowadays, corporate codes are increasingly seen as successful instruments to increase corporate responsible behaviour and responsible employee behaviour within these firms (cf. Andersen and Skjoett-Larsen 2009; Mamic 2005).

However, the problem is that the adoption of corporate codes does in fact not necessarily lead to more corporate responsible behaviour. Just as corporate codes accepted by over $80 \%$ of the publicly traded firms in the US could not prevent the financial crisis (Desjardins 2011), neither does the adoption of corporate codes automatically accomplish more responsible or accountable behaviour of firms. This is called the attitude-behaviour gap (O'Driscoll et al. 2013). From a normative ethical perspective, one can argue that corporate codes can undermine individual ethical responsibility and therefore prevent actual responsible behaviour by professionals (Schwartz 2000). For instance, it is argued that ethics starts with a moral impulse to help a child who is in danger, but that this moral impulse is neglected and instrumentalised in bureaucracies and governance structures such as corporate codes (Bauman 1989; Roberts 2001; Clegg et al. 2007). From a descriptive ethical perspective, one can argue that there is only a weak link between corporate codes and corporate responsible behaviour (Mathews 1988; Stevens 1994; Cassell et al. 1997; Schwartz 2002; Pater and van Gils 2003). Some scholars even draw the cynical conclusion that "codes, like laws, tend to keep the honest persons honest and have little impact on those who chose to ignore their precepts or who have never been exposed to their tenets" (Lee and Berleur 1994). Why should firms invest in corporate codes if their adoption at most result in being seen as ethical (Roberts 2001), but does not lead to more corporate responsible behaviour? The gap in current research is that we are in need of a theory that explains why corporate codes do not always lead to more corporate responsible behaviour, and provides a concept of corporate codes that in fact enhances and secures actual responsible behaviour in business.

From a management perspective, one can point to the drawbacks of most corporate codes; they are often vaguely defined, incomplete, not implemented, not independently monitored and/or subject to personal bias of senior managers (Bondy et al. 2007; Dunphy et al. 2007). Another difficulty concerns the alignment of different codes within networks or supply chains, especially in fields with conflicting interests (Nijhof et al. 2008; Boatright 2008). Finally, one can point to the minor role of codes compared with the organisational context and culture within which (un)ethical behaviour takes place (Cassell et al. 1997). We are therefore not only 
in need of a theory of corporate codes that actually enhances and secures actual corporate responsible behaviour, but also one that enables the integration of other organizational factors.

In this article, the nature of corporate codes is reflected upon ${ }^{1}$ in order to build a new theory of corporate codes that explains a) why codes often fail to enhance corporate responsible behaviour, b) how corporate codes can enhance actual corporate responsible behaviour, and c) which other organizational factors can increase the effectivity of corporate codes. ${ }^{2}$ Although many articles have been written which centre on their content and drawbacks in management practice, little work has been done on the nature of codes itself. Contrary to universalist - i.e. formal rules and procedures based - conceptualizations of corporate codes and contrary to instrumental conceptualizations, in which corporate codes are instrumental to corporate reputation and strategic competitive advantage, the hypothesis of this article is that codes have to be understood as performative speech acts, i.e. as sentences which do not primarily describe a state of affairs but do or perform something. A well-known example is the performative sentence: "I name this ship the Queen Elisabeth". This sentence does not describe a state of affairs - the name of the ship - but uttered in an appropriate context, this sentence performs the naming of the ship. Based on John Austin's speech act theory, corporate codes will be conceptualized as performative speech acts in this article, in which the behavioural aspect of corporate codes is stressed. A performative concept of corporate codes is characterized by 1) the existential self-performative of the firm identity; 2) This self-performative code is demanded by and responsive to the stakeholders of the firm; 3) Because corporate codes are structurally threatened by the possibility of infelicity or failure; 4) a firm's embracing of corporate codes does not only consist in corporate responsible behaviour in light of the code, but also in the incessant recapturing of the code in the struggle of firms against the possible incongruence between their ethical principles and their actual responsible behaviour.

The first contribution of this article is that it provides a theory of corporate codes that enables firms to enhance and secure corporate responsible behaviour, explains conceptually why codes sometimes fail, and indicates which organizational factors can enhance and secure the effectiveness of corporate codes. The second contribution of this article is that a performative concept of corporate codes helps to bridge classical dichotomies like individualist versus collectivist approaches of moral agency (cf. McMahon 1995; Valasquez 1983; Werhane 1985) and restrictive versus empowering ethics (Kjonstad and Willmott 1995), and opens a new perspective on the interaction between individual moral learning and development and the corporate institutionalisation of codes (cf. Constantinescu and Kaptein 2014).

In section one, the analysis starts with an introduction of Austin's concept of the performative. Four main characteristics of the performative will be distinguished, which will be applied to the concept of corporate codes in section two. With this, it will become clear how a performative concept of corporate codes, contrary to universalist and instrumentalist conceptualizations, has to be understood. In section three, it will be explored how the first two characteristics of a performative concept of corporate codes enhance corporate responsible

\footnotetext{
${ }^{1}$ Parts of this article are published earlier in another article, in which the performative speech act was applied on ethical oaths in economics and business in general, and the banker's oath which is recently introduced in the Netherlands in particular (Blok 2013a).

${ }^{2}$ There are many possible factors that may explain why codes often fail, like dishonesty, internal pressures, shifting priorities etc. The identification of these factors is beyond the scope of this article. In this article, only a conceptual explaination for this failure is explored, as opposed to an empirical explanation. It provides a conceptual explanation that should be researched empirically in relation to the other possible explanations in future research.
} 
behaviour, and how the third and fourth characteristic secure corporate responsible behaviour. By discussing the advantages of a performative concept of corporate codes, compared with universalist and instrumentalist conceptualizations, it will become clear that a performative concept of corporate codes can enhance and secure corporate responsible behaviour, because the performative involves corporate action and behaviour. At the same time, it will become clear that the effective adoption of a performative concept of corporate codes involves a radical shift of our conceptualizations of the nature, function and limitation of codes.

\section{John Austin and the Speech Act Theory}

The philosopher and founding father of the general theory of speech acts, John Austin, introduced a distinction between two types of sentences, namely constative and performative sentences. ${ }^{3}$ His speech act theory explains the ability of language to do other things with words than providing a mere description of reality.

In a constative sentence a state of affairs is described, asserting that something is the case. The constative sentence - for example, 'John and Mary are married' - asserts that John and Marry actually are married. While the primary function of the constative sentence is to say something and describe a state of affairs, the performative sentence is primarily a vehicle to do something and create something new (Austin 1961). If someone utters the sentence, 'I pronounce you man and wife', he definitely doesn't want to describe the marriage ceremony. With this sentence, he actually performs the marriage. And when John says 'I do', he is not describing his marriage but he is indulging in it.

Originally, Austin thought that the descriptive and performative functions of sentences were mutually exclusive (Austin 1962). In order to distinguish accordingly between constative and performative sentences, he first of all claimed that constative sentences primarily say something while performative sentences $d o$ something; the uttering of a performative is, or is part of, the performance of a certain kind of action (Austin 1962). Austin's second claim was that contrary to constative sentences, performatives cannot claim to be true or false. Constative sentences assert that something is the case and the correctness of these sentences can be tested by assessing whether what is said corresponds with what the world is like. This is impossible in case of performative sentences like, 'I name this ship the Queen Elisabeth' or 'I do'. These sentences do not primarily say something but create something new; the ship as Queen Elisabeth, John as married man. If this last sentence is uttered alone at home or in a context where no registrar is present, the sentence 'I do' isn't false but disabled, unsatisfactory or inappropriate. Such infelicities, as they are called by Austin, arise if simple rules are broken. For instance, the sentence 'I do' only makes sense if the very procedure for marrying actually exists and is accepted by both partners. An infelicity occurs too, if the circumstances in which the sentence 'I do' is uttered are inappropriate. Uttered alone at home or in a context where not the registrar but the cleaner is present, the act of marrying would not come off. There are also other ways in which infelicities can arise. Performatives like 'I do' presuppose certain feelings or intentions with regard to my future wife ${ }^{4}$. If a person says 'I do' without these feelings and

\footnotetext{
${ }^{3}$ After Austin, many other authors contributed to the conceptualization of the speech act theory, like Grice, Searle and Strawson. For the purpose of this article, however, a general introduction of the speech act theory based on Austin's work is sufficient.

${ }^{4}$ Austin is at least ambiguous here. On the one hand, he claims that the performative does not report inward and spiritual acts (Austin 1961: 236). On the other hand, the infelicity seems to arise out of the discrepancy between those spiritual acts (intentions) and actual behaviour.
} 
intentions, he or she is insincere. It is not the case that the person did not actually marry his wife, but that he married her in an insincere way (Austin 1961). Although this list of infelicities is not complete and in fact endless according to Austin, it becomes clear that performatives are not truth-evaluable but may be infelicitous.

A third distinction between constatives and performatives is that the latter are normally stated in the first person singular present indicative active; 'I do...', 'I name...', 'I bet...'. For Austin, the first person verb differs importantly from the use of other persons and other tenses in constative sentences: "For when we say 'I promise that...' we do perform an act of promising - we give a promise. What we do not do is to report on somebody's performing an act of promising" (Austin 1961: 242). The third characteristic of the performative is that it is stated in the first person singular and therefore, that the person who performs the speech act is actually involved in the performative.

Austin's distinction between constatives and performatives can shed some light on the discussion of oaths and codes on the one hand, and the weak link between corporate codes and actual corporate responsible behaviour on the other. While ethical oaths and codes are normally lumped together as 'forms of ethical statements implying a moral imperative' (Encyclopaedia of Bioethics, cited in Sulmasy 1999), Daniel Sulmasy used the distinction between constatives and performatives to distinguish between ethical oaths and codes.

A corporate code can be seen as a written set of rules and regulations that harmonize and standardize employee and management behaviour in order to minimize the risk of misconduct. In the classical view, these rules prescribe ethical behaviour. According to Sulmasy, codes are lists of moral do's and don'ts which are not stated in the first person singular, but in the second or third person. Based on this distinction, Sulmasy distinguishes between codes and oaths, because oaths are performative utterances in which the personhood of the swearer is involved in his commitment in future intentions, while codes are not (Sulmasy 1999).

This distinction is interesting, because the constative nature of codes could explain the weak link between corporate codes and actual responsible behaviour of corporations. On the one hand, the increased use of corporate codes does not help because of the constative nature of all codes; the adoption of such codes does not afford a firm directly to do something, i.e. to accomplish more responsible behaviour. On the other hand, if a professional oath can be understood as a performative oath, then the oath could be seen as a possible solution, which is often signalled in the ethical literature (Sulmasy 1999; Blok 2013a; de Bruin 2014); because of the performative nature of ethical oaths, a performative ethical oath would imply ethical behaviour and therefore, would be able to bridge the gap between the ethical principles the professional has and their ethical behaviour according to these principles. Is it therefore reasonable to reject at least the primacy of corporate codes in favour of ethical oaths in business?

Unfortunately, the issue at stake is not that simple, that constative codes and performative oaths can easily be distinguished and that one can argue for the latter, like Sulmasy seems to claim. First of all, the classical view of corporate codes as rules which prescribe or proscribe behaviour can be criticized. John Dienhart for instance has convincingly shown that codes are rarely sets of rules: "Many ethical codes begin by citing broad ethical concerns which help define how the profession promotes individual and social welfare. These goals are intended to guide professionals in their interpretation of the rest of the code and to help them make decisions in areas not specifically covered by the code" (Dienhart 1995: 427-428). A code is not a set of rules or do's and don'ts, but gives guidance and acts as a reference point for professionals facing complex ethical questions. 
Secondly, the strict distinction between constative and performative sentences can be criticized, as Austin himself already did. With regard to the performance of the performative, he gives various examples of performative sentences with no clear performance; the sentence 'I am sorry' can be understood as a performative - just like 'I apologize' - but also as the description of one's feelings for instance (Austin 1961). Furthermore, in constative sentences like 'I state that...', a similar act is performed as in performative sentences like 'I promise to...'. With regard to the non-truth-evaluableness of performatives, Austin states that a performative like a warning, although it cannot claim to be true or false, is in fact comparable with the facts. It is for instance possible to assess whether the warning was in order (Austin 1961). Also the third distinction - performatives are stated in the first person singular - has to be rejected, because a performative can also be stated in the passive form: 'You are hereby authorized...'. And when a person says, 'I order you to shut the door', the sentence is stated in the first person singular and not truth-evaluable, but he or she could perform exactly the same act by the imperative 'shut the door' (Austin 1961). In this respect, the problem of codes, i.e., that there is only a weak link between corporate codes and actual responsible behaviour of corporations, cannot be attributed to a strict distinction between constative and performative sentences (contra Sulmasy). And if codes can be conceived as performatives, then performative codes can be seen as a possible solution of the gap between ethical principles, understood as locutionary acts, and actual responsible behaviour according to these principles, understood as illocutionary and perlocutionary act.

Austin concludes that 'stating something is performing an act just as much as is giving an order or giving a warning; and we see, on the other hand, that, when we give an order or a warning or a piece of advice, there is a question about how this is related to fact which is not perhaps so very different from the kind of question that arises when we discuss how a statement is related to fact' (Austin 1961: 251). This general performativity of language is confirmed by social scientists who showed how the language of economics and business does not only explain reality, but also shapes the reality of institutional designs, management practices and social norms, thereby performing an act by the creation of corresponding behaviour (Ferraro et al. 2005).

Because Austin saw already in an early stage that a strict distinction between constative and performative sentences is not possible, he later developed a new theory about the speech act of all types of utterances; the locutionary, illocutionary and perlocutionary force of sentences.

The locutionary act of a sentence is the act of 'saying something' in a meaningful and grammatically correct way (Austin 1962: 94); the locutionary act of stating, 'I like management' for instance. The illocutionary act of a sentence corresponds with the performative; it concerns the act of asserting, questioning, promising etc. in a linguistic utterance. The speech act of uttering a sentence (locutionary act) can have the form of a question or promise, i.e. the performative or illocutionary force of questioning or promising. But the performance of an illocutionary act does not only require the act of a promise or warning by the speaker, but also the 'securing of uptake' (Austin 1962) by the one who perceives or hears the sentence; an illocutionary act like 'shut the door' will result, if understood correctly, in someone closing the door. The perlocutionary act concerns this result of the speech act in the hearer as a result of the speech act; closing the window as a result of the speech act 'close the window' for instance. The locutionary act of uttering a sentence about the presence of a door which is open, performs the illocutionary act of requesting someone to close the door, and the perlocutionary act of causing somebody to close the door. 
With this, a fourth characteristic of the performative occurs ${ }^{5}$. The performative or illocutionary force of a speech act requires that it is understood by the hearer; the performativity of a code requires that both the employee representing the firm and the customer of the firm are aware of and understand the code, i.e. the performative involves the 'securing of uptake'. Furthermore, the performative or illocutionary force of a speech act calls for 'conventional consequences' of the performative, i.e. the performative involves rights, commitments or obligations related to it (Austin 1962).

In the next section, the four characteristics of the performative which are distinguished in this section are applied -1) the involvement of action and behaviour, including consequences of the performative like rights and obligations; 2) the possibility of infelicity; 3) the selfinvolvement in the performative; 4) the securing of uptake - to the concept of corporate codes.

\section{Characteristics of a Performative Concept of Corporate Codes}

In the previous section, codes were defined as a set of guiding principles and underlying assumptions which act as a corporate reference point for professionals facing complex ethical questions. These codes may include specific measures (i.e. rules) to ensure ethical behaviour, but these rules are embedded in guiding ethical principles. Does the concept of the performative enable us to characterize and understand the nature of corporate codes?

In a famous article on the quest for a code of professional ethics, John Ladd has criticized the connection between ethical principles and codes, because "ethics is basically an openended, reflective and critical intellectual activity" which cannot be reduced to rules specifying concrete behaviour (Ladd 1985: 8; cf. Dienhart 1995). According to Ladd, codes violate the fundamental ethical principle of autonomy: "Ethics must, by its very nature, be self-directed rather than other-directed" (Ladd 1985: 8). While corporate codes require loyal adherence by employees and result in routinized compliance (Fisher 2001), Ladd emphasizes the autonomy of ethics, i.e. the fact that ethical principles are self-imposed. The opposition between ethical principles (self-imposed) and corporate codes (other-imposed) may be lifted if we acknowledge that corporate codes have to be understood as performative speech acts. Considering the self-imposedness of ethical principles, a comparable self-imposedness can be recognized in the performative; self-involvement is characteristic of the performative and therefore a conceptualization of corporate codes as performative speech acts can lift the opposition between selfversus other-imposedness in case of ethical principles. The self-involvement in the performative provides a first characteristic of a performative concept of corporate codes.

The self-involvement in the performative concept of corporate codes shows that acting in accordance with the code not only involves the commitment of an employee toward a future course of action, but primarily involves his or her identity as a person. If an employee for instance proclaims professional behaviour according to corporate ethical principles and values like loyalty and honesty, he not only intends to be honest but primarily to be the one who is loyal and honest. In other words, the proclamation of a corporate code cannot be understood instrumentally as a way to punish or reward employee behaviour, but is primarily a selfperformative of the one this professional wants to be; loyal for instance. This means that the

\footnotetext{
${ }^{5}$ Although Austin's later rejection of a strict distinction between constative and performative sentences has to be acknowledged, the concept of the performative is still useful to characterize the typical speech act of corporate codes. For this reason, the use of this concept is continued in this article in order to characterize the nature of corporate codes and codes of conduct (cf. Butler 1997; Sulmasy 1999; Briggs 2001).
} 
self-performative primarily articulates the identity of a professional, which then has consequences for his or her lifestyle, attitude and behaviour toward others. As a loyal and honest man, a professional intends for instance not to betray his client and to act in his or her best interest. The self-performative character of corporate codes shows therefore that they entail an existential moment, in which it is decided what type of person the professional wants to be; it concerns the identity as a professional and as a consequence his practical commitment, his attitudes and his feelings (Evens 1963). Therefore, the conceptualization of corporate codes as performative speech acts not only involves the self-imposed intention of a person to do something, but to be the one who is committed to some future course of action and is acting accordingly. The first characteristic of a performative concept of corporate codes is therefore, that it is an existential self-performative in which a person becomes the professional he or she is expected to want to be.

The self-performative character of corporate codes raises the question who is the 'self' in such a performative concept of codes. The first characteristic of the performative concept of corporate codes seems to be formulated from the perspective of the individual employee, while the corporate level of the code is neglected. In this article, however, a concept of corporate codes is adopted that acknowledges both the corporate level and the individual level of responsibility. On the one hand, corporate codes condition and restrain professional behaviour of employees within firms. On the other hand, it is only through actual employee behaviour within firms, that companies acquire the capabilities to apply and enact corporate codes in their business operations. It is through the dynamic interaction between professionals and the firm that responsible or accountable behaviour of individual professionals and firms is mutually enhanced (cf. Constantinescu and Kaptein 2014; see section 3 for this dynamic interaction). For this reason, the first characteristic of a performative concept of corporate codes has to be conceived both at individual and corporate level.

Corporate identity can be defined as the shared perceptions of the firm's central, distinctive and enduring qualities by the organizational members (employees and managers), which are embedded in the mission statement and the core values of the firm (Brickson 2007). The selfinvolvement in the performative concept of corporate codes does not only concern the identity of the individual professional, but also the corporate identity; the self-involvement in corporate codes shows that the promulgation of corporate codes involves the corporate identity, mission statements and core values of the firm, and that this identity is articulated by the first person perspective of the self-performative code.

The self-performative character of corporate codes raises the further question whether they have to be taken as subjective or even self-interested norms without universal validity. One of the fiercest criticisms of corporate codes is that there is no universally accepted set of ethical principles and that no one has the moral superiority to impose ethical principles to others. Also in case of the conceptualization of corporate codes as performative speech acts, the universal validity of ethical principles seems to be abandoned in favour of the self-performative of the identity of the firm that embraces the code. However, although it became clear that codes cannot be understood as universal rules in the previous section, and although the firm is involved in the self-performative code, the meaning of the performative is not, or at least not completely, dependent on their mission statements and core values. Why?

First of all, Robert Baker has shown that codes develop and grow in response to historical experiences within a profession or firm. Based on historical material, he has shown that ethical codes evolve through three stages: initially conduct is regulated by traditions of practice, which are formalized and rationalized in the second stage by the development of corporate codes. 
While adherence to these codes is personal and voluntary in the second stage, they take on an authoritative status in the third stage, capable of enforcing certain behaviour (Baker 2005). Corporate codes are not universal rules but have to be applied in an ever changing environment and for this reason, companies revise and adapt their codes and standards continuously (cf. Dienhart 1995). In this respect, the current discussion about the desirability of ethical codes in the banking sector can be understood as a response to the historical experience of the economic crisis, just like the tightening of corporate codes may be the result of stakeholder dialogue of a bank about the ethical acceptability of investments in the weapon industry.

This historical evolvement of corporate codes shows clearly that they

"develop incrementally, out of disparate precursor documents that were formulated for a variety of purposes as a field grappled with various issues and decided, one-by-one, how best to deal with them. By aggregating these statements of conduct into a single document that strives for a measure of universality and consistency, codifiers help a field to articulate the vision implicit in the standards that a field has already set for itself, so that this vision can be better understood and appreciated by its membership and by the world at large" (Baker 2005: 34-35).

When a firm promulgates a corporate code, the meaning of this code is not primarily or not only dependent on its intentions with it; it is rather embedded in broader ethical concerns regarding the moral responsibility of firms in society, which are historically determined. Indeed, if a firm embraces a corporate code, it even gets extra weight when it cites such historically determined concerns; by embracing the code of conduct of the Financial Service Council (FSC) for instance, a firm places itself in a tradition of the industry in which their business operations are embedded. This historical embeddedness of corporate codes shows that their meaning is not, or at least not completely, dependent on the intentions or the interests of the firm that embraces them. ${ }^{6}$

A second reason why the conceptualization of corporate codes as performative speech acts is not completely dependent on the intentions and interests of the firm comes up if the securing of uptake, i.e. the fourth characteristic of the performative, is considered. Corporate codes operate in a context of stakeholders, in which it has to be understood by the stakeholders of the firm. A code which is not stated in a conceivable language is not a code at all (cf. Austin 1962: 22). The performativity of the corporate code does not only consist in its being understood by the public context of stakeholders, but also in its being uttered for these stakeholders in order to enhance and secure actual corporate responsible behaviour.

A firm normally has much more market information than its customers. The firm is therefore able to maximize its own interest at the expense of customers or other stakeholders. Customers therefore face an adverse selection problem, since they are unable to distinguish between self-interested firms and firms that will work in the best interest of their customers (Beneish and Chatov 1993: 3; Dienhart 1995: 443). The public character of corporate codes materialized in publicly available and external audited annual CSR reports for instance - can help to decrease the risk of self-interest, because it enables the public examination of their effectivity by the stakeholders; the external auditors but also the general public are public witnesses of the corporate codes (cf. Newton 1981).

\footnotetext{
${ }^{6}$ One can also argue that the development of intentions and interests is historically embedded as well. The further elaboration of this question is beyond the scope of this article.
} 
The performativity of the code is therefore dependent on the securing of uptake by the stakeholders of the firm, and this prevents a subjective conception of corporate codes. A firm can never completely control the way the self-performative code is perceived by others. Rather, the history of corporate codes can be seen as an incremental development in response to the ever changing environment (technological, cultural, geographical etc.).

The securing of uptake provides a second characteristic of a performative concept of corporate codes. The meaning of the self-performative code (first characteristic of a performative concept of corporate codes) is not only dependent on the intentions (mission statements and core values) of the firm, but is determined by the public context (securing of uptake) and is articulated in the interaction with these stakeholders. This public context is never completely determinable; in-congruency between the corporate code and actual behaviour is always possible, since codes are not univocal and unambiguous and can always miss their mark; codes are often stated in general terms - integrity, honesty but also 'the best interest of the customer' for instance which cover several situations and can raise various expectations. In this respect, the self-performative of the identity, mission statement and core values of the firm is not only determined by the public context, but this public context always transcends the firm that embraces a corporate code.

From the perspective of stakeholder theory, the self-performative code can be seen as demanded by the stakeholders of the firm (Freeman 2010). External stakeholders like customers, suppliers and, in the end, society at large, can not only hold firms to the normative commitments which are stated in the self-performative code. Firms are also responsive to the demands of stakeholders because they represent the societies in which these firms operate. An example is the Dutch Rabobank, an international co-operative bank in the agri-food sector that explicitly tries to be responsive to a broad range of social and non-market demands by their stakeholders. Because the bank is held responsible for unsustainable behaviour of their clients (bad labour conditions, corruption, environmental pollution etc.), is expected not to be involved in unsustainable business practices like land grabbing and squeezing smallholders, and is expected to (financially) contribute to the development of food- and illiteracy programs, they apply a set of ethical principles and corporate codes to manage their operations responsibly and sustainably (Blok et al. 2013). The self-performative of the corporate identity, mission statement and core values of the firm (first characteristic of a performative concept of corporate codes) is therefore not only determined by their stakeholders (securing of uptake), but also demanded by these stakeholders. The responsiveness of a firm to these stakeholders enhances and secures its actual corporate responsible behaviour: In their utterance of a self-performative code in front of their stakeholders, firms become the one who are responsive to the demands of their stakeholders and the stakeholders become the one to which these firms are responsive in their corporate code. $^{7}$

This demand does not mean, however, that the success of the corporate code is guaranteed. The performative is not truth-evaluable, as we have seen in section 1. An example is the previously mentioned Rabobank that was recently involved in the manipulation of libor interest rates, notwithstanding their broad set of ethical principles and corporate codes.

\footnotetext{
${ }^{7}$ For the hermeneutic circle which is involved in this becoming, see Blok 2013b.
} 
According to Austin, such infelicities occur when any one of six general rules is broken. These general rules are:

a) The existence of an accepted procedure, like the procedure at a firm that new employees have to sign the code and/or that all employees have to sign the code every year again, year after year.

b) The circumstances should be appropriate for the invocation of the procedures involved, for instance a yearly day of reflection at which all employees discuss the values and norms of the firm, followed by a ceremony in which employees sign the code.

c) The procedures must be executed correctly.

d) The procedures must be executed completely, for instance the correct and complete text of a medical oath.

e) Congruency must exist between the intentions presupposed by the performative code and the actual intentions of the firm, for instance the intention to respect fair labour conditions and prevent child labour worldwide.

f) Congruency between the intentions presupposed by the performative code and actual corporate behaviour, for instance advising customers in their best interest.

The possibility of the infelicity of the performative shows a third characteristic of a performative concept of corporate codes. Are these rules conceivable as indispensable (although insufficient) conditions for the success of the performative in general and the performative concept of corporate codes in particular? Conditions a) to d) can be understood as conditions of the public context in which corporate codes are promulgated and accepted by stakeholders of the firm. Conditions e) and f) can guarantee corporate responsible behaviour, because they enforce congruency between corporate ethical intentions and actual responsible behaviour of the firm. If this is the case, it can be claimed that a self-performative code which meets these six conditions or rules, is able to guarantee corporate responsible behaviour. The self-performative code then implies corporate responsible behaviour and the six conditions guarantee the congruency between the corporate code and corporate responsible behaviour in general and the trustworthiness and integrity of corporate behaviour in particular.

Nevertheless, Austin is quite ambiguous in his assessment of these conditions, as Jacques Derrida has pointed out (Derrida 1982). On the one hand, he seems to admit that the possibility of infelicity is a structural characteristic of the performative, which can never be avoided completely (Austin 1962). On the other hand, this structural risk of failure is not seen as an essential characteristic of the performative, but as "an accidental, exterior one that teaches us nothing about the language phenomenon under consideration" (Derrida 1982: 323-324). Austin hopes to avoid the structural risk of failure of the performative by invoking the use of 'ordinary language' and 'ordinary circumstances' (Austin 1962). But if the possibility of infelicity is a structural possibility of a performative utterance, the possibility of infelicity is always there. And if the possibility of infelicity is granted, the risk of failure is not an accident but a structural condition of any corporate code. ${ }^{8}$ In this article, the structural possibility of infelicity is taken as the third characteristic of corporate codes. It explains how corporate codes can enhance and secure corporate responsible behaviour (i.e. actual ethical performance), for

\footnotetext{
${ }^{8}$ While Austin excludes the structural character of infelicity by stressing the concept of 'ordinary language', Derrida asks whether the general possibility of infelicity is necessarily that of failure, or an internal and positive condition of its possibility (Derrida 1982, 325).
} 
instance by following the six general rules, but also why codes sometimes fail to enhance corporate responsible behaviour. This is not or not primarily because the moral impulse of the professional is neglected and instrumentalized in corporate codes, but because of the structural possibility of infelicity of every code.

Is it necessary to draw such a negative conclusion about the fallibility of corporate codes? Various authors have pointed to these fundamental risks of failure of corporate codes (Dienhart 1995; Mathews 1988). This infelicity is obvious in the case of a banker who claims to act in the best interest of his customers but manipulates interest rates; he is faking or cheating and performs therefore an infelicity. But a firm may also fail notwithstanding its good intentions, for instance in case of unintended negative environmental or social impacts of innovative products and services. The normal response to such negative impacts is to develop governance structures like corporate codes, but the problem with these governance mechanisms is that they are retrospective and are less suitable to deal with highly uncertain and dynamic innovation processes (cf. Owen et al. 2013). This means that the code is always fallible and open for reassessment.

However, the fallibility does not have to be conceived merely at an individual level of professionals and top managers within companies. George DeMartino has pointed to the epistemic insufficiency of professionals with regard to complex fields of study like economics (DeMartino 2011). Their knowledge of economic interventions in order to improve economic development is not only limited, but it is acknowledged that all economic theories are insufficient (cf. Hofmann 2001). The economic crisis made clear that economics is a highly complex field of study and that the consequences of economic policies are unpredictable. In other words, the available knowledge is principally insufficient to predict the future and there will always be unintended consequences of economic interventions which can be harmful (DeMartino 2013). A comparable situation of 'imperfect foresight' is at stake in case of complex and uncertain innovations, and may have unintended negative impacts in the future. In an ever changing environment, one could argue, the possibility of infelicity is structural. This structurality of the possibility of infelicity doesn't imply that a firm cannot claim anymore to act in a responsible way. According to Derrida, this undecidability of ethical decisions makes firms and their employees primarily aware of the fundamental uncertainty or imperfect foresight in ethical decision making processes, which unsettles any kind of self-assurance in corporate ethical behaviour (cf. Painter-Morland 2011).

Negatively speaking, this leads to a relativistic position that suggests that the trustworthiness and integrity of all corporate codes can be questioned because of their structural infelicity; they have no universal validity nor are they necessary. At the same time, this infelicity can be taken in a positive way: the history of corporate codes can be seen as a history of their infelicity, which inspired the incremental development of these codes in response to the ever changing environment. In this respect, there is no difference between the adjustments of medical oaths because of new legislation with regard to abortion for instance, the reinforcement of corporate codes in economics and business in response to the economic crisis, and the development of new corporate codes in fields where high negative impacts may be expected in the future, like in case of industrial use of nanotechnology and synthetic biology. The third characteristic of a performative concept of corporate codes is, therefore, that the six rules are an indispensable condition for the self-performative code - they act as a guidance which 'reminds' firms and their employees of the ethical principles they embraced when they face complex ethical situations (cf. Passmore 1984) - although they are insufficient to guarantee 
corporate ethical behaviour; the conceptualization of corporate codes as performative speech acts acknowledges that they are structurally threatened by the possibility of failure.

The question remains, however, whether such a positive assessment of the infelicity of corporate codes implies a relativistic position with regard to ethical issues or not. How can be distinguished between responsible and irresponsible behaviour, if all codes are characterized by this structural possibility of infelicity? Although the structural possibility of the infelicity of corporate codes cannot be denied (third characteristic of a performative concept of corporate codes), the performative provides a way to distinguish between responsible and irresponsible behaviour. To see this, a further reflection on the three characteristics of a performative concept of corporate codes is needed.

Corporate codes are first of all characterized by the self-performative of the corporate identity, mission statement and core values of the firm. This self-performative code is demanded by the stakeholders and enhances and secures actual corporate responsible behaviour (second characteristic of a performative concept of corporate codes). The structural possibility of the infelicity of codes (third characteristic of a performative concept of corporate codes) made clear that the infelicity primarily concerns the identity and core values of the firm. Austin distinguished between two specific types of infelicity with regard to the identity of actors. The self-performative code is infelicitous if there is in-congruency between the performative promulgation of a code by a firm and its actual intentions, i.e. the actual mission and core values of the firm, or between these core values and its actual corporate behaviour.

Actual corporate behaviour is however not the result of the corporate code the firm has embraced, because the self-performative of the identity, mission and core values of the firm already implies and is some kind of action and has already behavioural consequences like rights and obligations (cf. $\S 1$ ); a corporate code is a code of conduct, i.e. it implies already actual behaviour. This idea is confirmed by the debate on performativity in management research, in which performative praxis is seen as main contributor in making theoretical constructs like codes a social reality (Cabantous and Gond 2011). ${ }^{9}$ To embrace a corporate code is to declare something about the firm's future actions and behaviour, but its actual commitment to the code only shows itself in its actual behaviour in accordance with the code in general, and with the rights and obligations involved in particular. Because the performative already involves some kind of action, the production of the corporate identity by the selfperformative code is already accompanied by a second production of the corporate identity as acting and living in light of the code.

With regard to corporate responsible behaviour, there are two possibilities. Either the firm is able to live up to the self-performative code, or the firm fails because it is not able or even not willing to live up to it. The only touchstone the firm has is the question whether the code is really able to determine and mark the corporate identity, mission statement and core values of the firm and its corporate behaviour accordingly. This either ... or shows that the second production cannot be seen as an accident or mere result of the first production - the selfperformative of the identity, mission and core values of the firm - but is essential for corporate

\footnotetext{
${ }^{9}$ The main difference between the concept of performativity of these authors and the author of this article is, that according to these authors, individual actors within the organisation performatively constitute the social reality of theoretical constructs like ethical decision making, while this article argues that the promulgation of the code itself is self-performative and constitutes the identity of the actors involved, i.e. firms and individual employees (cf. Callon 1998). The further elaboration of the similarities and differences between a performative concept of corporate codes and the broader discussion of performative praxis in management research and economic sociology is beyond the scope of this article.
} 
codes. Why? Because of the structural risk of infelicity or failure, a firm only lives up to the code by its actual corporate behaviour in light of the code; only by living and acting in light of the code does the self-performative of the code become real. This means that actual corporate responsible behaviour enables stakeholders to test whether a firm that embraces a code of conduct actually lives up to these standards.

The testability of corporate responsible behaviour, which is implied in the conceptualization of corporate codes as performative speech acts, can also shed some light on the content of the code. The content of the code has to be understood as the behavioural consequences - rights and obligations - of the corporate identity, mission and core values of the firm. The fourth characteristic of a performative concept of corporate codes is, therefore, that the selfperformative is not restricted to the intention of firms to commit themselves to some future action, but involves their actual corporate behaviour according to these rights and obligations which are stated in the content of the code. Actual responsible behaviour according to the rights and obligations is the only touchstone the firm and its stakeholders have to distinguish between responsible and irresponsible corporate behaviour.

Is it legitimate to claim, then, that companies that are able to live up to the code by their corporate behaviour in light of the code, in fact perform more responsible behaviour? Because of the structural infelicity of every code, their actual living up to the code does not only consist in corporate behaviour in light of the code, but also in the incessant appropriation and reappropriation of the code in their struggle against its possible infelicity. The possible infelicity doesn't relieve the firm from ethical decision making and corporate responsible behaviour, but makes it aware that corporate responsible behaviour is inseparable from the question whether the firm actually made the right decision, whether its corporate codes are still appropriate and responsive to the demands of the stakeholders etc. Corporate responsibility does therefore not only consist in actual corporate behaviour according to the content of the code, but also in putting its actual behaviour into question. The appropriation and re-appropriation of the corporate code by a firm doesn't intend to avoid the possibility of infelicity, as Austin's strategy does, but sees the possibility of infelicity precisely as a driver to performatively produce actual corporate behaviour in light of the code, i.e. to produce corporate responsible behaviour.

\section{Discussion and Conclusion: Toward a Performative Concept of Corporate Codes in Business}

In section two, four characteristics of a performative concept of corporate codes are distinguished which constitute a theory of corporate codes that enhances and secures corporate responsible behaviour. A performative concept of corporate codes consists 1) in the selfperformative of the corporate identity, mission and core values of the firm; 2) This performative code is demanded by and responsive to the stakeholders of the firm; 3) Because of the structural possibility of infelicity of corporate codes, the 4) embracing of these codes does not only consist in actual corporate behaviour in light of the code by firms and their employees, but also in the incessant recapturing of the code in their struggle against its possible infelicity.

Contrary to an instrumentalist conception of the nature of corporate codes, which conceptualizes codes as instruments to increase the corporate reputation and the strategic competitive advantage of the firm, the performative concept of corporate codes stresses the selfinvolvement of the corporate identity, mission statement and core values of the firm in corporate responsible behaviour; the performative code is not only self-imposed in the sense 
that it involves the corporate intentions of firms to commit themselves to some future course of action, but also in the sense that it involves the identity of the firm that is committed to corporate responsible behaviour. The advantage of the conceptualization of corporate codes as performative speech acts is that this existential moment of the performative is stressed.

The emphasis on this existential moment is particularly important if the criticism of universal ethical principles and norms are taken into account. According to this criticism, there are no universally accepted principles or norms a firm can commit itself to; these ethical principles are in fact relative to cultural or social differences. But if corporate codes are conceptualized as performative speech acts, precisely this relativity of the code to the corporate identity, mission and core values of the firm is emphasized. Not the universal validity of the content of the code is embraced in corporate codes - the history of corporate codes can be seen as an incremental development of codes in response to the ever changing environment in general and the infelicity of existing codes in particular - but the existential decision of the firm to live and act in light of the code, here and now.

There is also another advantage of stressing the existential moment in the development and adoption of corporate codes. Based on the work of Hopwood, Cassell et al. (1997) have shown that the internalisation of corporate codes by individual recipients of these codes will have a positive impact on their individual behaviour. In order to have a positive impact, these principles or norms should be "either directly or indirectly ... internalised by the members of the enterprise and operate as personal controls over attitudes and behaviour" (Hopwood 1974: 31). The internalisation of corporate codes is expected to have a positive impact on individual ethical behaviour of employees in light of the code.

With regard to the content of corporate codes, it is argued in the literature that it should be characterized by clarity, comprehensiveness and enforceability in order to be effective (Raiborn and Payne 1990). On the one hand, a clear and distinct formulation of the content of corporate codes could indeed prevent the ambiguity of their content and provide guidelines for employees within the firm on how to proceed in case of conflicts of interest for instance. On the other, the improvement of the clarity and comprehensiveness of its content doesn't prevent the possible infelicity of corporate codes. Contrary to legalistic or instrumental approaches of the content of corporate codes, in which the content is stated in terms of moral do's and don'ts, the advantage of a performative concept of corporate codes is that it shows the importance of actual corporate behaviour in light of the code and in accordance with the rights and obligations involved. This actual corporate responsible behaviour is already implied in the self-performative of the corporate identity. The conceptualization of corporate codes as performative speech acts enables therefore the rejection of the classical criticism that codes don't change actual behaviour - codes are too broadly formulated to guide people's behaviour (Bowie 1979, cited in Dienhart 1995) - because the self-performative code already involves some kind of action and has already behavioural consequences like rights and obligations. A further advantage of such a behavioural approach of corporate codes is that it prevents an 'ethics of Narcissus', i.e. an approach in which firm's being seen as ethical is stressed, rather than their actual taking responsibility in their business operations (Roberts 2001). Only by living and acting in light of the code is the performativity of the code real.

With this, the first contribution of this article becomes clear. It provides a theory of corporate codes that enables firms to enhance and secure corporate responsible behaviour; the conceptualization of corporate codes as performative speech acts can enhance corporate responsible behaviour because a performative code essentially involves action and behaviour. With this, it also becomes clear that a performative concept of corporate codes can bridge 
classical dichotomies like individualist versus collectivist approaches of moral agency and restrictive versus empowering ethics, and opens a new perspective on the interaction between individual moral learning and development on the one hand and the corporate institutionalisation of corporate codes in enhancing and securing corporate responsible behaviour on the other.

The second contribution of this article is that it provides a theory of corporate codes that explains why corporate codes sometimes fail to enhance and secure corporate responsible behaviour. This structural infelicity of the performative shows that corporate responsible behaviour in light of the code is insufficient to perform corporate responsible behaviour. The epistemic insufficiency of actors with regard to complex fields of study like economics, business and innovation has to be acknowledged. The fundamental uncertainty and high risk in business planning and policy making and the potential harm these businesses can cause for others - customers, employees, civil society etc. (DeMartino 2011) - shows that the introduction of corporate codes cannot solve all problems regarding corporate responsible behaviour; failure is possible and nothing can guarantee responsible behaviour. Corporate responsible behaviour does not only consist therefore in the effort of companies to live and act in light of the code, but in their incessant recapturing of its content in their struggle against its possible infelicity as well.

The advantage of the conceptualization of corporate codes as performative speech acts is that it acknowledges the fundamental possibility of infelicity, which makes clear that the sole introduction of corporate codes in firms is not sufficient. It should be accompanied by the introduction of formal and informal control systems. These control mechanisms enable the monitoring and evaluation of corporate responsible behaviour in accordance with the code which is promulgated. In addition to the self-control of the firm which is at stake in the selfperformative code (guidance), one can also think of formal controls like rules and procedures and informal controls like common customs and values in professional life (cf. Cassell et al. 1997). The introduction of formal and informal controls at firm level not only enhances ethical behaviour by individual employees, but also at corporate level.

John Boatright has pointed to the importance of institutional design to ensure ethical behaviour (Boatright 2011). Institutional design concerns the governance structure, the separation of functions etc., in which professional behaviour of employees is normally embedded; professionals have specific roles and responsibilities and decision-making follows certain procedures for instance. One can also think of interventions like training, monitoring systems, reward systems, ethical officers, recruitment policies etc. (McDonald and Nijhof 1999). The third contribution of this article is that it provides a theory of corporate codes that integrates other organizational factors like internal and external control in order to enhance and secure corporate responsible behaviour. The conceptualization of corporate codes as performative speech acts shows that corporate codes have to be embedded in the institutional design of firms. These institutional aspects can be conceived as the indispensable (although insufficient) conditions of corporate codes; the existence of accepted procedures, circumstances for the invocation of the procedures, the correct execution of the procedures etc. are an integral part of the corporate codes, which enables the monitoring and evaluation of corporate responsible behaviour in accordance with the code and in this way, ensures corporate responsible behaviour.

As a consequence, corporate codes have to be seen as a dynamic interaction between individual employee behaviour and the institutional design of corporations (cf. Constantinescu and Kaptein 2014). The embeddedness of employee behaviour in the institutional design does 
not only ensure more responsible behaviour at the individual level, but also at the corporate level of institutions.

The emphasis on the importance of institutional design as an integral part of corporate codes has an important advantage. It is argued that unethical behaviour of managers is not due to individual moral deficiencies. Jackall for instance argues that the bureaucratic structures of modern organizations encourage unethical behaviour of managers (Jackall 1988; Roberts 2001). Although the existential moment in the performative code is stressed in this article, the performance of corporate responsible behaviour should be facilitated by these gestures embedded in the organizational design of the firm.

What are the consequences of the conceptualization of corporate codes as performative speech acts for their adoption in business practices? First, as a consequence of the selfperformative code, in which a firm becomes corporate responsible, the introduction of corporate codes should be accompanied by policies that enable reflection on what the code means for individual employees, what are the causes of unethical corporate behaviour and how to establish ethical behaviour in the business operations of the firm (cf. Anderson and Escher 2010). These opportunities for reflection could be provided by in company education programs, but also during work team and board discussions for instance (see Hill and Rapp 2014 for a concrete strategy to enhance corporate responsible behaviour in this way). The policies will increase the self-involvement of employees and the internalization of corporate codes.

Because of the structural possibility of the infelicity of corporate codes, due to the complexity, uncertainty and high risks involved in business and economics, firms and their employees should take these uncertainties into account in their business planning and policy making, resulting in more moderate and safer business strategies. Furthermore, the acknowledgement of their epistemic insufficiency should lead to more caution in corporate activities in high risk markets. This modesty will not solve the problem of uncertainty and high risk, but enables companies to "manage ethically but imperfectly a problem that cannot be eradicated" (DeMartino 2011: 187-188).

When the possibility of infelicity, failure or even insufficiency is stressed in the concept of corporate codes, it becomes clear that it is insufficient to promulgate a code once and for all. In one way or another, firms and their employees have to repeat and re-appropriate the code again and again by dedicating themselves continuously to its content. In several consultancy firms, for instance, employees have to sign the code of conduct every year again. Policies that enable the reflection on ethical issues could help to appropriate and re-appropriate the corporate code (cf. Painter-Morland 2010). The re-appropriation of the code is however not only an individual affair of employees. In the literature, it is argued that the creation of a collective agreement on the shared principles or codes within the firm is also important (Warren 1993; Hill and Rapp 2014).

A performative concept of corporate codes can not only be perceived as a set of principles which are dependent on corporate intentions, but also as demanded by the stakeholders of the firm. This demand-character of the stakeholders - customers, suppliers, but also civil society etc. - has to stressed in a performative concept of corporate codes. As a consequence, the reappropriation of the code cannot be seen as the repetition of the mission and core values of the firm, but as a dynamic product of an ongoing conversation (and negotiation) with these stakeholders. In fact, it is this conversation and negotiation with critical stakeholders that will improve the quality of the code (cf. Garegnani et al. 2013) and will enhance and secure corporate responsible behaviour. They should therefore communicate with stakeholders on a structural basis in order to assess the applicability of the content of the code in an ever 
changing environment and to re-appropriate its content. These conversations help to assess the clarity of the content of corporate codes and their applicability in an ever changing environment, and to enable the re-appropriation of its content if necessary. Furthermore, both in education programs and in professional life, knowledge, attitudes and skills with regard to learning (cf. Stevens 2008), reflection (cf. Kjonstad and Willmott 1995), value attunement (cf. Swanson 1999) and dealing with the interests of multiple stakeholders should be stimulated and facilitated by policies, governance structures etc.

The development of these abilities cannot remove the criticism that the interests of multiple stakeholders can conflict with each other. On the one hand, these possible conflicts are acknowledged and mitigated by the capability of companies to deal with multiple stakeholders. On the other hand, the fundamental possibility of the infelicity of corporate codes in economics and business has to be accepted. Just as corporate codes cannot guarantee corporate responsible behaviour, these additional requirements cannot entirely prevent unethical behaviour. Nevertheless, the conceptualization of corporate codes as performative speech acts as described in this article can contribute to more corporate responsible behaviour.

\section{Compliance with Ethical Standards}

Conflict of Interest On behalf of all authors, the corresponding author states that there is no conflict of interest.

Open Access This article is distributed under the terms of the Creative Commons Attribution 4.0 International License (http://creativecommons.org/licenses/by/4.0/), which permits unrestricted use, distribution, and reproduction in any medium, provided you give appropriate credit to the original author(s) and the source, provide a link to the Creative Commons license, and indicate if changes were made.

\section{References}

Andersen, M., and T. Skjoett-Larsen. 2009. Corporate social responsibility in global supply chains. Supply Chain Management 14(2): 75-86.

Anderson, M., and P. Escher. 2010. The MBA oath: setting a higher standard for business leaders. New York: Penguin. Austin, J.L. 1961. Philosophical papers. London: Oxford UP.

Austin, J.L. 1962. How to do things with words. Oxford: Clarendon.

Baker, R. 2005. A draft model aggregated code of ethics for bioethicists. The American Journal of Bioethics 5(5): $33-41$.

Bauman, Z. 1989. Modernity and the holocaust. Cambridge: Polity Press.

Beneish, M.D., and R. Chatov. 1993. Corporate codes of conduct: economic determinants and legal implications for independent auditors. Journal of Accounting and Public Policy 12(1): 3-35.

Blok, V. 2013a. The power of speech acts: reflections on a performative concept of ethical oaths in economics and business. Review of Social Economy 71(2): 187-208.

Blok, V. 2013b. Toward the rehabilitation of the will in contemporary philosophy. Journal of the British Society for Phenomenology 44(3): 286-301.

Blok, V., A. Sjauw-Koen-Fa, and O. Omta. 2013. Effective stakeholder involvement at the Base of the Pyramid: the case of Rabobank. International Food and Agribusiness Management Review 16(A): 39-44.

Boatright, J.R. 2008. Ethics in finance. Oxford: Blackwell.

Boatright, J.R. 2011. Trust and integrity in Banking. Ethical Perspectives 18(4): 473-489.

Bondy, K., D. Matten, and J. Moon. 2007. Codes of conduct as a tool for sustainable governance in MNCs. In Corporate governance and sustainability, ed. S. Benn and D. Dunphy. London: Routledge.

Brickson, S.L. 2007. Organizational identity orientation: the genesis of the role of the Firmand distinct forms of social value. Academy of Management Review 32(3): 864-888.

Briggs, R.S. 2001. Words in action. Speech act theory and biblical interpretation. New York: T\&T Clark Ltd.

Butler, J. 1997. Sovereign performatives in the contemporary scene of utterance. Critical Inquiry 23(2): 350-377. 
Cabantous, L., and J.-P. Gond. 2011. Rational decision making as performative praxis: explaining rationality's Eternel Retour. Organization Science 22(3): 573-586.

Callon, M. 1998. The laws of the markets. Oxford: Blackwell Publishers.

Cassell, C., P. Johnson, and K. Smith. 1997. Opening the black box: corporate codes of ethics in their organisational context. Journal of Business Ethics 16(10): 1077-1093.

Clegg, S., M. Kornberger, and C. Rohodes. 2007. Organizational ethics, decision making, undecideability. Sociological Review 55(2): 393-409.

Constantinescu, M., and M. Kaptein. 2014. Mutually enhancing responsibility: a theoretical exploration of the interaction mechanisms between individual and corporate moral responsibility. Journal of Business Ethics. doi:10.1007/s10551-014-2161-4.

de Bruin, B. 2014. Pledging integrity: oaths as forms of business ethics management. Journal of Business Ethics. doi:10.1007/s10551-014-2504-1.

DeMartino, G.F. 2011. The economist's oath. Oxford: Oxford UP.

DeMartino, G.F. 2013. Epistemic aspects of economic practice and the need for professional economic ethics. Review of Social Economy 71(2): 166-186.

Dentoni, D., V. Blok, R. Wesselink, and T. Lans. 2012. Developing human capital for Agri-food firms' multi-stakeholder interactions. International Food and Agribusiness Management Review 15(A): 61-68.

Derrida, J. 1982. Margins of Philosophy, trans. Alan Bass, Chicago: University of Chicago Press [originally published in French in 1972].

DesJardins, J. 2011. An introduction to business ethics, 4th ed. New York: McGraw-Hill.

Dienhart, J. 1995. Rationality, ethical codes, and an egalitarian justification of ethical expertise: implications for professionals and organisations. Business Ethics Quarterly 5(3): 419-450.

Dunphy, D., A. Griffiths, and S. Benn. 2007. Organisational change for corporate sustainability. A guide for leaders and change agents of the future. London: Routledge.

Evens, D. 1963. The logic of self-involvement. London: SCM.

Ferraro, F., J. Pfeffer, and R.I. Sutton. 2005. Economics language and assumptions: how theories can become self-fulfilling. Academy of Management Review 30(1): 8-24.

Fisher, C. 2001. 'Managers' perceptions of ethical codes: dialectics and dynamics. Business Ethics: A European Review 10(2): 145-156.

Freeman, R.E. 2010. Strategic management: A stakeholder approach. Boston: Pitman.

Garegnani, G.M., E.P. Merlotti, and A. Russo. 2013. Scoring firms' codes of ethics: an explorative study of quality drivers. Journal of Business Ethics. doi:10.1007/s10551-013-1968-8.

Gunningham, N., R.A. Kagan, and D. Thornton. 2004. Social license and environmental protection: why businesses Go beyond compliance. Law \& Social Inquiry 29(2): 307-341.

Hill, R.P., and J.M. Rapp. 2014. Codes of ethical conduct: a bottom-up approach. Journal of Business Ethics 123: 621-630.

Hofmann, B. 2001. On the value-ladenness of technology in medicine. Medicine, Health Care and Philosophy 4(3): 335-346.

Hopwood, A. 1974. Accounting and human behaviour. London: Prenctice Hall.

Jackall, R. 1988. Moral mazes: The world of corporate managers. Oxford: Oxford UP.

Kjonstad, B., and H. Willmott. 1995. Business ethics: restrictive or empowering? Journal of Business Ethics 14(6): 445-464.

Ladd, J. 1985. The quest for a code of professional ethics. In Ethical issues in the use of computers, ed. D.G. Johnson and J.W. Snapper. Belmont: Wadsworth.

Lee, J., and J. Berleur 1994. Progress towards a World-Wide Code of Conduct. Proceedings of the conference on Ethics in the computer age.

Mamic, I. 2005. Managing global supply chain: the sports footwear, appare and retail sectors. Journal of Business Ethics 59(1): 81-100.

Mathews, M.C. 1988. Strategic intervention in organisations. London: Sage.

McDonald, G., and A. Nijhof. 1999. Beyond codes of ethics: an integrated framework for stimulating morally responsible behaviour in organisations. Leadership and Organisation Development Journal 20(3): 133-146.

McMahon, C. 1995. The ontological and moral status of organizations. Business Ethics Quarterly 5: 541-554.

Newton, L. 1981. Lawgiving for professional life: reflctions on the place of the professional code. Business and Professional Ethics Journal 1.

Nijhof, A., T. de Bruijn, and H. Honders. 2008. Partnerships for corporate social responsibility: a review of concepts and strategic options. Management Decision 46(1): 152-167.

O'Driscoll, A., M. Claudy, and M. Peterson. 2013. Understanding the attitude-behavior gap for renewable energy systems using behavioral reasoning theory. Journal of Macromarketing 33(4): 273-287. 
Owen, R., J. Stilgoe, P. Macnaghten, M. Gorman, E. Fisher, and D. Guston. 2013. A framework for responsible innovation. In Responsible innovation. Managing the responsible emergence of science and innovation in society, ed. R. Owen, J. Bessant, and M. Heintz, 27-50. Chichester: Wiley.

Paine, L., Deshpande, R., Margolis, J.D., and K.E. Bettcher 2005. Up to code. Does your company's conduct meet world-class standards? Harvard Business Review, R0512H.

Painter-Morland, M. 2010. Questioning corporate codes of ethics. Business Ethics: A European Review 19(3): $265-279$.

Painter-Morland, M. 2011. Moral decision-making. In Business ethics and continental philosophy, ed. M.

Painter-Morland and R. ten Bos, 117-140. Cambridge: Cambridge UP.

Passmore, J. 1984. Academic ethics. Journal of Applied Philosophy, 1(1).

Pater, A., and A. Van Gils. 2003. Stimulating ethical decision-making in a business context: effects of ethical and professional codes. European Management Journal 21(6): 762-772.

Raiborn, C.A., and D. Payne. 1990. Corporate codes of ethics: a collective conscience and continuum. Journal of Business Ethics 9(11): 879-889.

Robert, J. 2001. Corporate governance and the ethics of narcissus. Business Ethics Quarterly 11(1): 109-127.

Schwartz, M.S. 2000. Why ethical codes constitute an unconscionable regression. Journal of Business Ethics 23(2): 173-184

Schwartz, M.S. 2002. A code of ethics for corporate code of ethics. Journal of Business Ethics 41(1): 27-43.

Stevens, B. 1994. An analysis of corporate ethical code studies: 'where do we go from here?'. Journal of Business Ethics 13(1): 63-69.

Stevens, B. 2008. Corporate ethical codes: effective instruments for influencing behaviour. Journal of Business Ethics 78(4): 601-609.

Sulmasy, D.P. 1999. What is an oath and why should a physician swear one? Theoretical Medicine and Bioethics 20(4): 329-346.

Swanson, D. 1999. Towards an integrative theory of business and society: a research strategy for corporate social performance. Academy of Management Review 24: 506-521.

Valasquez, M.G. 1983. Debunking corporate moral responsibility. Business Ethics Quarterly 13: 531-562.

Warren, R.C. 1993. Codes of ethics: bricks without straw. Business Ethics: A European Review 2(4): $185-191$.

Werhane, P.H. 1985. Persons, rights, and corporations. Englewood Cliffs: Prentice Hall.

Vincent Blok is associate professor in Business Ethics and Responsible Innovation at the Management Studies Group and the Philosophy Group, Wageningen University. Blok's research group is specialized in sustainable entrepreneurship, business ethics and responsible innovation in the private sector and is involved in several (European) research projects. Blok's work appeared amongst others in Journal of Business Ethics, Journal of Cleaner Production, Entrepreneurship \& Regional Development and Journal of Responsible Innovation. See www.vincentblok.nl for more information about his current research. 